\title{
PENGEMBANGAN FILM PEMBELAJARAN DAILY LIVING SKILL SEBAGAI PENUNJANG PEMBELAJARAN BINA DIRI DI SLB TUNAGRAHITA
}

\author{
Ihsyahrul Rohmat ${ }^{1}$, I Gede Parta Sindu ${ }^{2}$, P Wayan Arta Suyasa ${ }^{3}$ \\ Jurusan Pendidikan Teknik Informatika \\ Universitas Pendidikan Ganesha \\ Singaraja, Bali
}

e-mail: younggrafika@gmail.com ${ }^{1}$, partha.sindu@undiksha.ac.id ${ }^{2}$, arta.suyasa@undiksha.ac.id ${ }^{3}$

\begin{abstract}
Abstrak
Tujuan dari penelitian pengembangan media ini adalah untuk membantu menunjang proses pembelajaran bina diri siswa tunagrahita ringan dalam mempelajari bagaimana merawat pakaian dan menjaga keselamatan berlalu lintas. Film pembelajaran ini memiliki alur cerita yang sama persis dengan keadaan nyata. Pengembangan film pembelajaran bina diri daily living skill merawat pakaian dan menjaga keselamatan berlalu lintas menggunakan model ADDIE. Yang terdiri dari lima tahap yaitu Analisis (Analyze), Desain (Design), Pengembangan (Development), Implementasi (Implementation), dan Evaluasi (Evaluation), Pengembangan produk media pembelajaran dengan model ini dapat menghasilkan produk yang baik, mengingat pada setiap tahap yang dilalui dapat melakukan evaluasi. Produk yang telah dihasilkan dilakukan uji validitas yang dilakukan oleh para ahli untuk mengetahui kelayakan media film pembelajaran. Selain uji validitas dilakukan pengujian untuk mengetahui respon penonton setelah menggunakan media film pembelajaran bina diri daily living skill merawat pakaian dan menjaga keselamatan berlalu lintas dilakukan dengan metode angket yang memiliki hasil dengan persentase rata-rata sebasar $82,5 \%$ yang artinya media ini masuk kategori baik.
\end{abstract}

Kata kunci: Media, Film Pembelajaran, Bina Diri, ADDIE

\begin{abstract}
The purpose of this research and developing this film media is to help and support the learning process of mentally retarded student about how to caring for the clothes and maintaining traffic safety. This film has an exact storyline based on daily life. Filmmaking about daily living skills for caring the clothes and maintaining traffic safety using the ADDIE model. There are five steps in this ADDIE model, including Analysis, Design, Development, Implementation, and Evaluation The products that have been produced are validity tests conducted by experts to determine the feasibility of learning film media.. Media development with this model can produce a good product, considering at each steps can be evaluated. Testing to find out the response of the audience after applying daily living self skills learning film about how to caring the clothes and maintaining traffic safety do by questionnaire method, have a representation of result of with an average $82,5 \%$, which is means this media has a good category.
\end{abstract}

Keywords : Media, Learning Film, Self Development, ADDIE

\section{PENDAHULUAN}

Direktorat Pembinaan Sekolah Luar Biasa menerangkan dalam panduan pelaksanaan kurikulum pendidikan khusus bahwa sistem pendidikan pada jenjang Sekolah Dasar Luar Biasa (SDLB) tunagrahita mengacu pada kurikulum 2013 khusus dengan pendekatan pelayanan individual. Saat ini, persentase kurikulum di SDLB Tunagrahita meliputi 30\% akademik dan $70 \%$ keterampilan vokasional ${ }^{[3]}$. Salah satu mata pelajaran keterampilan 
vokasional yang terdapat di Sekolah Luar Biasa Tunagrahita adalah mata pelajaran bina diri. Program bina diri memiliki peran sentral dalam mengantarkan peserta didik dalam melakukan bina diri untuk dirinya sendiri, seperti merawat diri, mengurus diri, menolong diri, komunikasi dan adaptasi lingkungan sesuai dengan kemampuannya. Melalui pembelajaran bina diri diharapkan dapat hidup mandiri di keluarga, sekolah, dan masyarakat. Pembelajaran bina diri diarahkan untuk mengaktualisasi dan mengembangkan kemampuan peserta didik dalam melakukan bina diri untuk kebutuhan dirinya sendiri sehingga siswa tidak membebani orang lain.

Berdasarkan hasil observasi dan wawancara yang peneliti lakukan dengan Ibu Dra. M.C. Eksi Muniarti, M.Pd salah satu guru kelas di Sekolah Luar Biasa Negeri 2 Singaraja pada mata pelajaran bina diri untuk siswa kelas VI tunagrahita ringan telah diketahui bahwa siswa telah diajarkan bermacam-macam ADL (Activity Daily Living) seperti kegiatan pada aspek merawat diri, mengurus diri, menolong diri dan berkomunikasi dengan orang lain namun siswa masih belum menguasai ADL (Activity Daily Living) pada aspek menolong diri. Telah diketahui bahwa siswa masih belum bisa memahami bagaimana cara menolong diri seperti merawat pakaian milik sendiri, bagaimana menjaga keselamatan diri sendiri saat di jalan raya karena dari jumlah 8 siswa baru 3 siswa yang mengetahui bagaimana cara menolong diri. Karena pada saat proses pembelajaran bina diri guru sebagai pengajar tidak bisa mendampingi siswa secara penuh dikarenakan guru juga harus menyajikan materi kepada siswa serta minimnya media pembelajaran khusus untuk mata pelajaran bina diri. Sedangkan siswa dengan kelainan kecerdasan, mental, fisik, dan sosial membutuhkan pendampingan khusus dalam hal perhatian, dan pengarahan yang bertahap.

Seperti yang telah kita ketahui bahwa dalam kegiatan pembelajaran siswa tunagrahita tidak sama seperti siswa normal pada umumnya. Siswa tunagrahita membutuhkan pengkondisian khusus dan pendampingan guru yang maksimal. Selama ini metode pembelajaran yang digunakan masih berupa ceramah disertai demonstrasi sedangkan kemampuan siswa sangat lemah dalam ingatan dan berpikir secara abstrak terutama ketika guru ingin memberikan materi bina diri pada kompetensi menolong diri dengan materi merawat pakaian dan menjaga keselamatan berlalu lintas guru kesulitan dalam menyampaikan materi karena dalam waktu yang bersamaan guru harus dapat mengkondisikan siswa dan juga mengkondisikan pengajaran secara seimbang. Berdasarkan kondisi tersebut, maka dalam pelaksanaan pembelajaran bina diri dengan kompetensi menolong diri yang meliputi materi merawat pakaian dan menjaga keselamatan dan tata tertib berlalu lintas di jalan raya siswa membutuhkan alat bantu media yang dapat mempermudah proses belajar mengajar pada mata pelajaran bina diri. Namun alat bantu media yang dibutuhkan saat ini belum tersedia.

Alat bantu media yang selama ini dibutuhkan adalah media yang mampu membantu guru dalam menyajikan materi, serta dapat dilihat prosesnya seperti peristiwa sebenarnya. Alat bantu media yang tepat untuk mata pelajaran ini salah satunya adalah media film pembelajaran ${ }^{[4]}$.

Berdasarkan uraian permasalahan yang telah disampaikan maka perlu dikembangkan media film pembelajaran mata pelajaran bina diri untuk membantu siswa dalam belajar dan memudahkan guru dalam menyajikan materi pada pelaksanaan pembelajaran untuk siswa tunagrahita ringan di Sekolah Luar Biasa Tunagrahita. Adapun judul yang diangkat dalam penelitian ini adalah "Pengembangan Film Pembelajaran Daily Living Skill sebagai Penunjang Pembelajaran Bina Diri di SLB Tunagrahita".

\section{KAJIAN TEORI}

\section{A. Program Bina Diri}

Program bina diri memiliki peran sentral dalam mengantarkan peserta didik dalam melakukan bina diri untuk dirinya sendiri, seperti merawat diri, mengurus diri, menolong diri, komunikasi dan adaptasi 
lingkungan sesuai dengan kemampuannya. Melalui pembelajaran bina diri diharapkan dapat hidup mandiri di keluarga, sekolah, dan masyarakat. Pelaksanaan pengembangan bina diri haruslah berorientasi pada kebutuhan peserta didik tunagrahita, memperhatikan lingkungan yang kondusif, menggunakan pembelajaran terpadu, mengembangkan keterampilan hidup atau kecakapan hidup, menggunakan berbagai media dan sumber belajar yang bervariasi dan pendekatan pembelajaran yang berorientasi pada prinsip-prinsip perkembangan dan kemampuan peserta didik tunagrahita. Sehingga dalam pelaksanaannya diperlukan beberapa hal yang perlu diperhatikan agar dapat berjalan secara optimal sesuai dengan yang diharapkan dimulai dengan kesiapan peserta didik dalam menerima latihan, belajar dalam keadaan nyaman dan diusahakan peserta didik dibawa dalam kondisi yang kongkrit dan nyata supaya pengalaman belajar yang didapat peserta didik utuh dan menyeluruh, latihan diberikan berdasarkan tahapan tugas (task analisys), berikan penguatan berupa pujian dan lainnya, latihan dilakukan secara berulang-ulang. Pendekatan yang diterapkan dalam pembelajaran bina diri bersifat perbaikan tingkah laku. Program Bina Diri menurut Astati dibagi menjadi tujuh macam, meliputi: (1) Kebutuhan Merawat Diri (2) Kebutuhan Mengurus Diri, (3) Kebutuhan Menolong Diri, (4) Kebutuhan Komunikasi, (5) Kebutuhan Sosialisasi, (6) Kebutuhan Keterampilan Hidup, (7) Kebutuhan Mengisi Waktu Luang [1].

\section{B. Media Pembelajaran}

Proses pembelajaran terdapat dua unsur yang sangat penting, yaitu metode pembelajaran dan media pembelajaran. Metode pembelajaran dan media pembelajaran saling berkaitan. Pemilihan suatu metode pembelajaran akan mempengaruhi jenis media pembelajaran yang akan digunakan.

Lebih lanjut jika dicari artinya, kata media berasal dari bahasa latin yang merupakan bentuk jamak dari medium, secara harfiah berarti perantara atau pengantar. Media adalah semua bentuk perantara yang digunakan oleh manusia untuk menyampaikan atau menyebar ide, sehingga ide, pendapat, atau gagasan yang dikemukakan atau disampaikan bisa sampai pada penerima ${ }^{[6]}$. Sesuai dengan pengertian media yang dikemukakan di atas dapat disimpulkan bahwa media pembelajaran merupakan suatu perantara yang digunakan pendidik dalam menyampaikan pesan kepada peserta didik untuk mencapai tujuan pembelajaran.

\section{Pengertian Film}

Menurut UU RI No.33 Tahun 2009 tentang perfilman, film adalah media komunikasi massa merupakan sarana pencerdasan kehidupan berbangsa, pengembangan potensi diri, pembinaan akhlak mulia, pemajuan kesejahteraan rakyat, serta wahana promosi Indonesia di dunia internasional. Sehingga film dan perfilman Indonesia perlu dikembangkan dan dilindungi ${ }^{[12]}$.

Menurut Wibowo mengatakan bahwa film adalah alat untuk menyampaikan berbagai pesan kepada khalayak melalui sebuah media cerita. Film juga merupakan medium ekspresi artistik sebagai suatu alat bagi para seniman dan insan perfilman dalam rangka mengutarakan gagasangagasan dan ide cerita. Secara esensial dan subtansial film memiliki kekuatan yang akan berimplikasi terhadap komunikan masyarakat ${ }^{[13]}$.

Sedangkan menurut Munadi, Film adalah gambaran teatrikal yang diproduksi secara khusus untuk dipertunjukan di gedung-gedung bioskop dan televisi atau sinetron yang dibuat ${ }^{[7]}$.

Berdasarkan pengertian menurut para ahli, dapat disimpulkan bahwa film adalah karya cipta seni dan budaya yang merupakan media komunikasi untuk menyampaikan pesan, gagasan-gagasan, dan ide cerita yang dibuat berdasarkan sinematografi sehingga bisa dipertunjukan ke masyarakat.

D. Film sebagai Media Pembelajaran 
Di era perkembangan ilmu pengetahuan dan teknologi, siswa dapat belajar di mana, kapan, dan apa saja sesuai dengan minat dan gaya belajar siswa. Dalam kenyataan seperti ini, guru tidak lagi berperan sebagai satu-satunya sumber belajar, akan tetapi kini guru berperan sebagai desainer pembelajaran. Sebagai desainer pembelajaran guru dituntut agar dapat merancang pembelajaran dengan memanfaatkan berbagai sumber belajar dan jenis media yang sesuai agar pembelajaran berlangsung secara efektif dan efisien. Selain itu guru juga berperan merancang agar siswa memperoleh pengalaman belajar, sebab pada hakikatnya belajar itu adalah proses perubahan perilaku berkat adanya pengalaman ${ }^{[8]}$.

\section{METODE PENELITIAN}

Penelitian ini merupakan jenis penelitian dan pengembangan (Research and Development). Borg dan Gall menyatakan bahwa Research and Development (R\&D) merupakan metode penelitian yang digunakan untuk mengembangkan atau memvalidasi produkproduk yang digunakan dalam Pendidikan dan pembelajaran ${ }^{[5]}$. Metode penelitian pengembangan ini digunakan untuk menghasilkan produk tertentu dalam menguji keefektifan, keefisienan, dan kemenarikan produk agar bermanfaat dalam pembelajaran.

Model pengembangan yang digunakan dalam penelitian ini adalah model ADDIE. Model ADDIE merupakan salah satu model penelitian pengembangan yang dikembangkan oleh Dick dan Carry pada tahun 1996 untuk merancang sistem pembelajaran. Model ini dipilih karena model ADDIE sering digunakan untuk menggambarkan pendekatan sistematis untuk pengembangan intruksional. Model ADDIE merupakan model pembelajaran yang bersifat umum dan sesuai digunakan untuk penelitian pengembangan. Ketika digunakan dalam pengembangan, proses ini dianggap berurutan, di mana hasil evaluasi setiap tahap dapat membawa

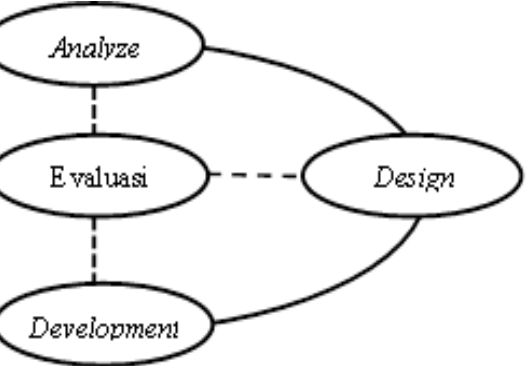

Development

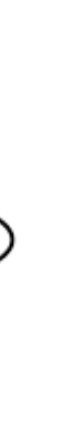

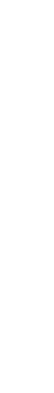

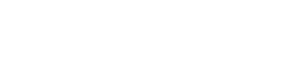

pengembangan pembelajaran ke tahap sebelumnya ${ }^{[2]}$.

Adapun alasan pemilihan model ADDIE adalah karena model ADDIE menggambarkan proses pengembangan yang sederhana yaitu terdiri dari 5 tahapan yang berurutan secara sistematis dan interaktif. Selain itu, model ADDIE sering digunakan untuk menggambarkan pendekatan sistematis untuk pengembangan pembelajaran.

$$
\text { 1. Analisis (Analysis) }
$$

Tahapan Analisis pada penelitian Pengembangan Film Pembelajaran Daily Living Skill sebagai Penunjang Pembelajaran Bina Diri di SLB Tunagrahita terdiri dari proses pembuatan sinopsis cerita, kebutuhan fungsional, kebutuhan non fungsional, analisis alat, analisis STP, dan analisis SWOT.

\section{Desain (Design)}

Tahapan desain pada Pengembangan Film Pembelajaran Daily Living Skill sebagai Penunjang Pembelajaran Bina Diri terdiri dari penyusunan jadwal, penyusunan skenario, pembuatan desain konsep art, pembuatan storyboard, pemilihan tokoh dan pengisi suara, perekaman video pada setiap adegan, penggabungan video dengan animasi Vincen, dubbing, musik, efek suara. 
3. Pengembangan

(Development)

Tahapan

(Development)

pengembangan

Living

Living Skill sebagai Penunjang

Pembelajaran Bina Diri terdiri dari dua tahapan yaitu tahap Produksi dan tahap Pasca Produksi. Tahap produksi terdiri dari perekaman video, animasi gerak karakter, animasi lip sync dan animasi setting / latar belakang, animasi efek visual spesial, animasi kamera, animasi pencahayaan.

4. Implementasi

(Implementation)

Film yang sudah dihasilkan dari proses Development akan dievaluasi oleh para ahli untuk mengetahui apakah film pembelajaran daily living skill yang dihasilkan sudah sesuai dengan standar produksi film pembelajaran. Hasil dari evaluasi kemudian akan menentukan apakah film pembelajaran yang dihasilkan perlu direvisi kembali atau tidak. Pada tahap ini angket uji ahli menggunakan angket skala dua yaitu sesuai dan tidak sesuai, bila terdapat ketidaksesuaian dari hasil angket uji ahli maka akan dilakukan revisi kembali, jika tidak ada ketidaksesuaian maka akan dilanjutkan ketahap selanjutnya yaitu melakukan uji lapangan.

5. Evaluasi (Evaluation)

Evaluasi dilakukan pada setiap tahap proses pembuatan agar diketahui kelayakan dari masing-masing proses, sehingga dapat dilanjutkan pada proses berikutnya.

\section{HASIL DAN PEMBAHASAN}

1. Hasil Penelitian

Pengembangan Film Pembelajaran Daily Living Skill untuk Penunjang Pembelajaran Bina Diri Di SLB Tunagrahita menggunakan metode penelitian Research and Development (R\&D) dengan model pengembangan ADDIE. Melalui tahapan pengembangan $A D D I E$ telah dihasilkan sebuah film pembelajaran yang diharapkan dapat digunakan sebagai sumber dan media belajar siswa di sekolah luar biasa tunagrahita dalam kegiatan pembelajaran bina diri. Adapun hasil pengembangan film pembelajaran bina diri adalah sebagai berikut :

\section{A. Analisis}

Tahapan

Analisis

pada

Pengembangan film pembelajaran bina diri "Daily Living Skill" terdiri dari proses pembuatan cerita sinopsis, kebutuhan fungsional, kebutuhan non fungsional, sasaran pengguna, analisis SWOT dan analisis STP. Adapun hasil dan rincian dari tiap-tiap proses adalah sebagai berikut :

Tahap pembuatan sinopsis peneliti melakukan evaluasi terkait dengan cerita mengingat cerita yang dimuat harus singkat dan jelas tanpa harus menghilangkan inti dari tujuan pembelajaran, sehingga peneliti melakukan evaluasi alur cerita/sinopsis kepada ahli isi dan ahli media dalam bentu Tahap analisis merupakan tahapan yang harus dilakukan pertama kali seperti pengumpulan informasi dan kebutuhan secara lengkap kemudian dianalisis kebutuhan yang diperlukan. Media film pembelajaran yang dikembangkan diharapkan berguna bagi anak-anak tunagrahita untuk mengetahui dan memahami bagaimana merawat pakaiannya sendiri serta menjaga keselamatan berlalu lintas. Setelah dilakukan analisis media pembelajaran yang akan dikembangkan maka didapatkan kebutuhan dan tujuan sebagai berikut :

\section{Kebutuhan Fungsional}

(1) Film Pembelajaran Bina Diri Daily Living Skill mampu menampilkan logo Universitas Pendidikan Ganesha, logo Jurusan Pendidikan Teknik Informatika pada credit di akhir film, dan logo LCl (Labroratory of Cultur Informatics) pada caption pojok atas sepanjang durasi film. (2) Film Pembelajaran Bina Diri Daily Living Skill mampu menampilkan Low Third berupa caption penekanan-penekanan dalam film. (3) Film Pembelajaran Bina Diri Daily Living Skill mampu menampilkan subtitle dengan bahasa Indonesia. (4) Film Pembelajaran Bina Diri Daily Living Skill mampu memperdengarkan narasi dan dialog berbahasa Indonesia dengan jelas. (5) Film Pembelajaran Bina Diri Daily Living 
Skill mampu memperdengarkan efek suara dan backsound tanpa mengganggu suara dialog atau narasi.

\section{Kebutuhan Non Fungsional}

(1) Melalui hasil uji validitas film pembelajaran Bina Diri Daily Living Skill dapat diterapkan sebagai media pembelajaran bina diri di SLB Tunagrahita. (2) Melalui hasil uji efektifitas film pembelajaran Bina Diri Daily Living Skill dapat meningkatkan motivasi dan hasil belajar siswa pada pembelajaran bina diri di SLB Tunagrahita. (3) Film Pembelajaran Bina Diri Daily Living Skill dapat menghubungkan siswa dengan pengalaman yang terpampang melalui bahasa gambar yang ditampilkan.

\section{Kebutuhan Perangkat Keras}

Dalam pengembangan film pembelajaran bina diri "Daily Living Skill" perangkat keras (hardware) yang diperlukan agar dapat menampilkan Film Pembelajaran Bina Diri Daily Living Skill dengan kualitas maksimal adalah perangkat keras yang mendukung dengan video dengan resolusi HD (1280 pixel x 720 pixel).

4. Kebutuhan Perangkat Lunak Dalam pengembangan Film Pembelajaran Bina Diri "Daily Living Skill" perangkat lunak (software) yang diperlukan agar mampu menampilkan Film Pembelajaran Bina Diri "Daily Living Skill" dengan kualitas maksimal adalah media player yang mendukung video dengan resolusi HD (1280 pixel x 720 pixel) dengan aspek rasio 16:9 dan format MP4.

Analisis SWOT digunakan untuk menimbang sebuah sumber referensi film dalam segi kekuatan, kelemahan, kesempatan yang bisa didapat, serta ancaman yang mungkin terjadi pada film tersebut. Adapun analisis SWOT film pembelajaran daily living skill sebagai penunjang pembelajaran bina diri sebagai berikut.

\begin{tabular}{|l|l|}
\hline SWOT & \multicolumn{2}{|c|}{ Film Pembelajaran } \\
\hline Strength & $\begin{array}{l}\text { Mengangkat materi tentang } \\
\text { bagaimana menjaga } \\
\text { peraturan dan keselamatan di } \\
\text { jalan raya serta menjaga } \\
\text { keindahan rumah dan } \\
\text { merawat pakaian. } \\
\text {-Memberikan media edukasi } \\
\text { yang baik untuk anak-anak } \\
\text { sekolah dasar luar biasa. } \\
\text {-Terjalinnya komunikasi yang } \\
\text { baik dengan guru sekolah } \\
\text { dasar luar biasa sehingga } \\
\text { proses pembuatan film ini } \\
\text { mendapat dukungan penuh } \\
\text { dari sekolah. }\end{array}$ \\
$\begin{array}{ll}\text { Keterbatasan dana dalam } \\
\text { proses penggarapan film. } \\
\text {-Jumlah crew yang terbatas } \\
\text { dan masih tergolong } \\
\text { amatiran. } \\
\text {-Alat yang digunakan dalam } \\
\text { pembuatan film ini juga masih } \\
\text { terbilang belum maksimal. }\end{array}$ \\
\hline Nantinya film ini akan menjadi \\
media pembelajaran kepada \\
anak-anak sekolah dasar luar \\
biasa dalam bentuk film \\
pembelajaran \\
mengangkat tema daily living \\
skill.
\end{tabular}

Setelah melewati analisis SWOT, dilakukan penetapan target audiens sebagai ketentuan penyebaran film ke masyarakat luas. Analisis STP yang terdiri dari beberapa kriteria berupa pemilahan (segmentating), target (targeting), dan penempatan (positioning). 


\begin{tabular}{|l|l|l|}
\hline \multicolumn{2}{|c|}{ STP } & \multicolumn{1}{c|}{ Project } \\
\hline \multirow{4}{*}{$\begin{array}{l}\text { Segmentasi } \\
\text { \& Targeting }\end{array}$} & Deografis & $\begin{array}{l}\text { Ukuran daerah : } \\
\text { Ditujuhkan untuk } \\
\text { seluruh daerah Bali } \\
\text { bahkan Indonesia. }\end{array}$ \\
\cline { 2 - 3 } & & $\begin{array}{l}\text { Usia : 10 - 17 tahun } \\
\text { Gender : Laki-laki } \\
\text { dan perempuan } \\
\text { Pendidikan : SD - } \\
\text { SMP }\end{array}$ \\
\cline { 2 - 3 } Positioning & $\begin{array}{l}\text { Kelas Sosial : Anak } \\
\text { Berkebutuhan } \\
\text { Khusus Tunagrahita }\end{array}$ \\
\hline & $\begin{array}{l}\text { Film pembelajaran daily living skill } \\
\text { mengangkat cerita bagaimana } \\
\text { anak bisa hidup mandiri } \\
\text { khususnya pada menjaga } \\
\text { keselamatan diri di jalan raya da } \\
\text { bagaimana anak bisa menjaga } \\
\text { keindahan dan kebersihan rumah } \\
\text { dan merawat pakaiannya sendiri. }\end{array}$ \\
\hline
\end{tabular}

\section{B. Desain}

Tahap desain pada Pengembangan Film Pembelajaran Bina Diri Daily Living Skill terdiri dari penyusunan jadwal, penyusunan skenario, pembuatan desain konsep art, pembuatan storyboard, pemilihan pemeran dan pengisi suara, perekaman video pada setiap adegan, perekaman dialog, pembuatan efek suara dan musik.

Pada tahap desain peneliti juga melakukan evaluasi, hal ini dilakukan untuk mengetahui kesesuaian desain dengan penerapan pada media dan kesesuaian dengan isi, evaluasi dilakukan oleh ahli isi dan ahli media dan desain. Dalam bentuk pengisian angket yang dilakukan dengan penyebaran angket validitas.

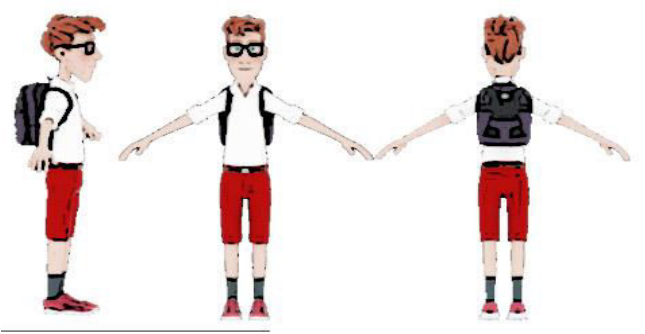

Hasil dari tahap pengembangan pada film pembelajaran bina diri daily living skill merawat pakaian dan menjaga keselamatan berlalu lintas meliputi :

1. Hasil pengembangan antar muka opening

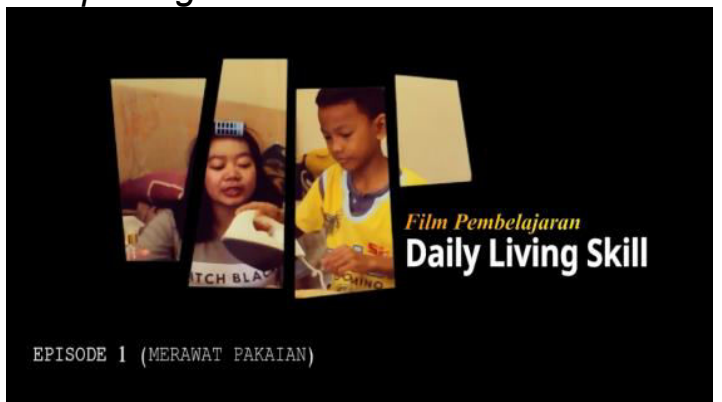

Gambar 2. Opening film pembelajaran daily living skill

2. Hasil pengembangan antar muka keadaan mencuci pakaian

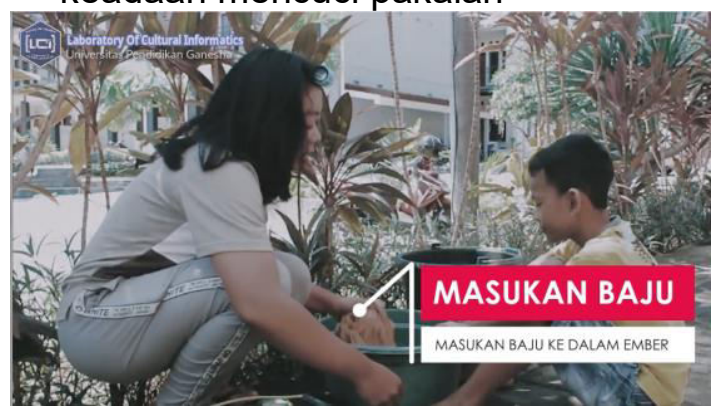

Gambar 3. Adegan mencuci pakaian

3. Hasil pengembangan antar muka keadaan menjemur pakaian

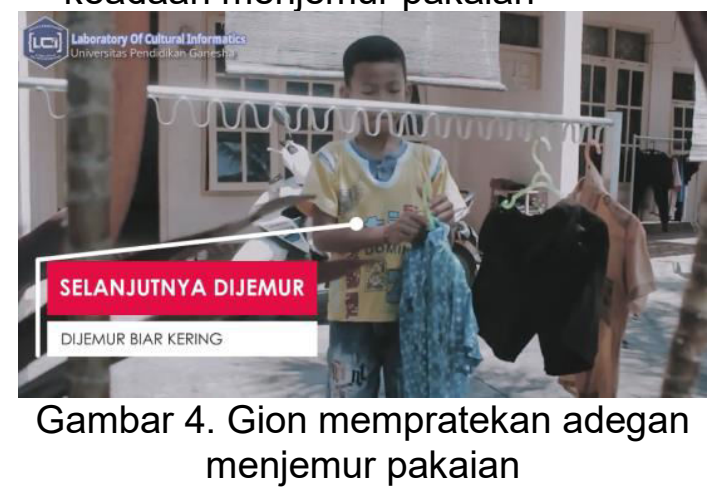

4. Hasil pengembangan antar muka keadaan menyetrika pakaian

Gambar 1. Desain Konsep Art

C. Pengembangan 


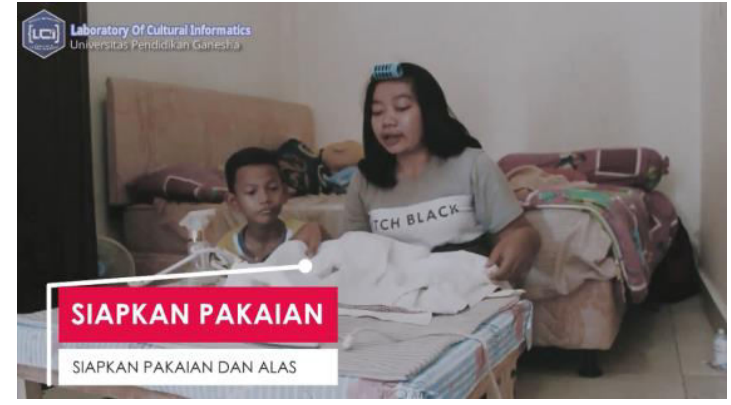

Gambar 5. Gion dan tante mensetrika pakaian

5. Hasil pengembangan antar muka keadaan taat lalu lintas

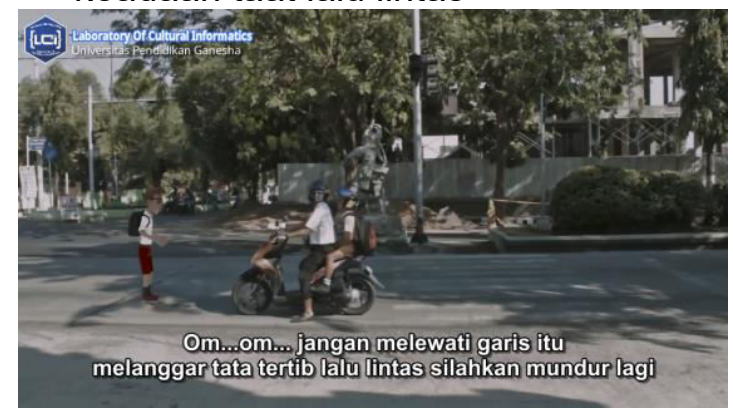

Gambar 6. Vincen mengingatkan Gion dan ayahnya melanggar lalu lintas

6. Hasil pengembangan antar muka keadaan dilarang putar balik

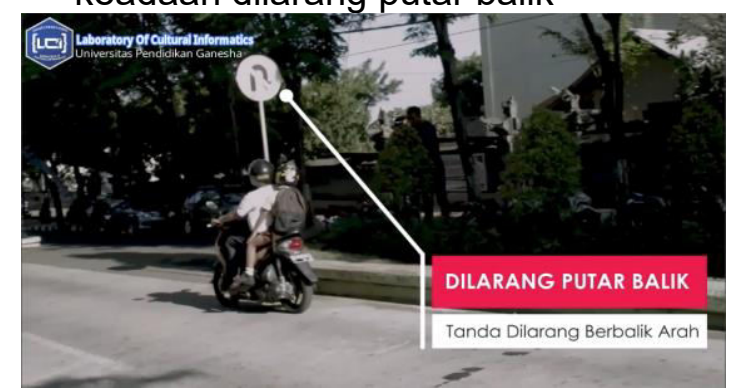

Gambar 7. Gion dan ayah berangkat ke sekolah

7. Hasil pengembangan antar muka keadaan dilarang putar balik

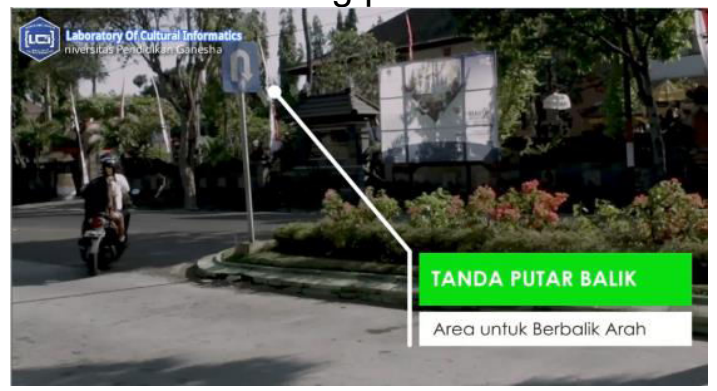

Gambar 8. Gion dan ayah putar balik
8. Hasil pengembangan antar muka keadaan berjalan dijalan raya yang tidak benar

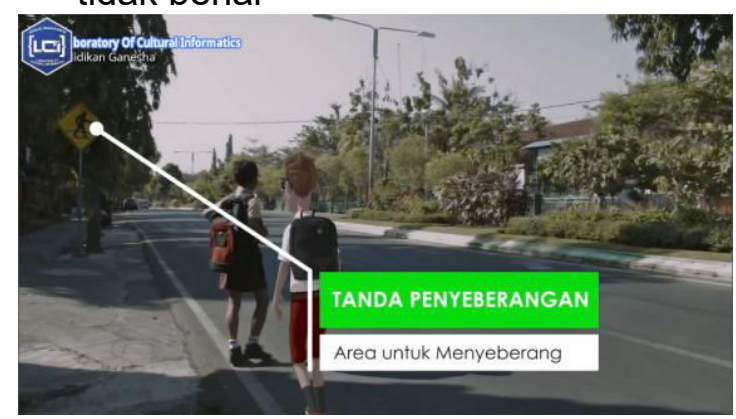

Gambar 9. Gion dan Vincen mau menyeberang jalan

9. Hasil pengembangan antar muka keadaan menyeberang jalan

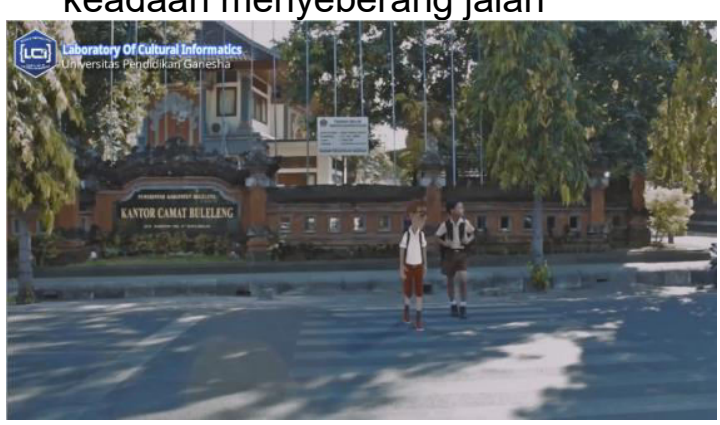

Gambar 10. Gion dan Vincen pulang sekolah

10. Hasil pengembangan antar muka credit film pembelajaran

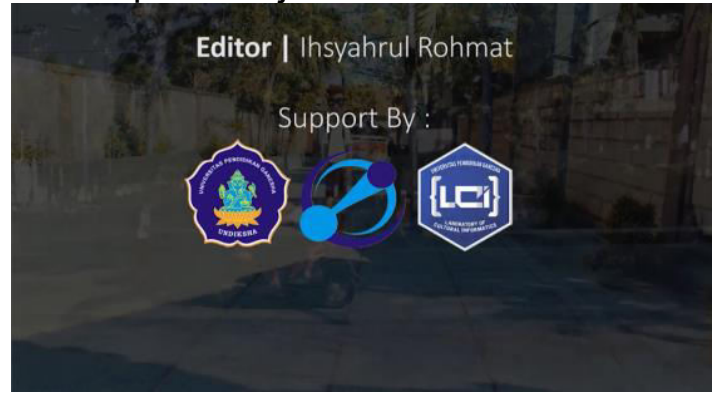

Gambar 12. credit diakhir film pembelajaran bina daily living skill

D. Implementasi

1) Uji Validitas Ahli Isi

Uji validitas ahli isi digunakan untuk mengetahui kesesuaian isi dari film pembelajaran agar sesuai dengan kriteria dan kebutuhan penonton usia 10 sampai 17 tahun.

2) Uji Validitas Ahli Media dan Desain 
Uji ahli media dan desain dilakukan untuk mengetahui kesesuaian secara teknis pada pembuatan visual dan audio film. Evaluasi

3) Publikasi

Hasil akhir pengembangan film pembelajaran bina diri daily living skill merawat pakaian dan menjaga keselamatan berlalu lintas akan disebarkan dalam bentuk DVD dan melalui internet dengan ke youtube dan media sosial.

4) Uji Efektifitas

Selain uji respon dilakukan uji efektifitas dengan pemberian pre test dan post test untuk mengetahui peningkatan hasil belajar setelah diterapkannya media pembelajaran.

5) Uji Respon Guru

Selain efektifitas peneliti juga melakukan uji respon guru untuk mengetahui respon guru terhadap pengembangan media film pembelajaran bina diri daily living skill dalam proses pembelajaran.

6) Uji Respon Penonton

Uji respon pengguna dilakukan untuk mengetahui kepuasan dan tanggapan pengguna terhadap media film pembelajaran bina diri daily living skill merawat pakaian dan menjaga keselamatan berlalu lintas. Uji respon penonton dilakukan dengan cara menyebarkan 20 angket kepada 20 responden yang telah menggunakan media pembelajaran bina diri daily living skill merawat pakaian dan menjaga keselamatan berlalu lintas.

\section{E. Evaluasi}

Evaluasi dilakukan pada setiap tahap proses pembuatan agar diketahui kelayakan pada proses sehingga dapat dilanjutkan pada proses berikutnya. Adapun aspek yang perlu dilakukan evaluasi adalah sebagai berikut:

1) Uji Validitas Ahli Isi

Uji validitas ahli isi digunakan untuk mengetahui kesesuaian isi dari film pembelajaran agar sesuai dengan kriteria dan kebutuhan penonton usia 10 sampai 17 tahun. Uji ahli isi peneliti melibatkan dua guru yang mengajar bina diri di SLB Negeri 2 Buleleng. Uji ahli isi film pembelajaran bina diri daily living skill dilakukan sebanyak dua kali mengingat hasil tahap pertama terdapat beberapa ketidak sesuaian dengan representasi $80 \%$ pada tahap ini peneliti mendapat masukan dari uji ahli isi yaitu yang pertama kejelasan informasi lebih ditekankan, tata letak sebaiknya dipikirkan kembali, dan yang terakhir kualitas film lebih ditingkatkan lagi. Selanjutnya peneliti melakukan beberapa perbaikan dan dilanjutkan dengan uji tahap kedua. Pada tahap kedua peneliti mendapatkan kesesuaian dengan representasi $100 \%$ dari kedua ahli isi. Pada uji ahli isi peneliti menggunakan rumus Gregory, hasil perhitungan sebagai berikut :

$$
\text { Validitas }=\frac{D}{A+B+C+D}=\frac{15}{15}=1,00
$$

2) Uji Validitas Ahli Media dan Desain

Uji ahli media dan desain dilakukan untuk mengetahui kesesuaian secara teknis pada pembuatan visual dan audio film. Uji ahli media dan desain peneliti melibatkan dua dosen dari jurusan pendidikan teknik informatika Undiksha. Hasil uji ahli media film pembelajaran bina diri dailiy living skill merawat pakaian dan menjaga keselamatan berlalu lintas dilakukan satu tahap oleh dua ahli media dan desain, mengingat hasil dari tahap pertama mendapatkan kesesuaian dengan representasi $100 \%$ dari ahli media dan desain namun terdapat saran dan masukan dari salah satu ahli media dan desain adapun saran dan masukan yang diberikan kepada peneliti yaitu yang pertama kualitas gambar dibuat lebih terang, penggunaan kata bahasa pada subtitle gunakan bahasa Indonesia baik dan benar, berilah animasi untuk membuat penekanan pada informasi yang menurut peneliti lebih penting untuk ditonjolkan kepada penonton dan sudah direvisi dan diperbaiki. Pada uji ahli media peneliti menggunakan rumus Gregory, hasil perhitungan sebagai berikut :

$$
\text { Validitas }=\frac{D}{A+B+C+D}=\frac{15}{15}=1,00
$$


Berdasarkan perhitungan hasil Uji Ahli pada film pembelajaran bina diri daily living skill merawat pakaian dan menjaga keselamatan berlalu lintas didapatkan hasilnya yaitu 1 yang berarti Validitas Sangat Tinggi.

\section{3) Uji Efektifitas}

Pada pengujian efektifitas peneliti menggunakan soal pre test dan post test, dengan hasil rata-rata pre test 65,00 dan hasil rata-rata post test 84,06 dengan hasil perhitungan efektifitas sebesar $79,16 \%$ yang berarti media pembelajaran yang dibuat sangat efektif.

$$
\begin{aligned}
& N-\text { Gain }=\frac{\text { Skor posttest }- \text { Skor pretest }}{\text { Skor maksimal }- \text { Skor pretest }} \\
& N-\text { Gain }=\frac{84,06-65}{100-65}=\frac{19,06}{35}=0,5445
\end{aligned}
$$

4) Uji Respon Guru

Pelaksanaan pengujian respon oleh guru dilakukan dengan guru bina diri di Sekolah Luar Biasa Negeri 2 Buleleng dengan hasil representasi poin sebesar 39.

$\bar{x}=\frac{\sum x}{N}$

Keterangan :

$\bar{x} \quad$ : Rata-rata kelas untuk skor respon guru dan siswa

$\sum x$ : Jumlah skor respon guru siswa

$N \quad$ : Banyaknya guru dan siswa

Sedangkan untuk mencari mean ideal (Mi) dan standar deviasi ideal (SDi) digunakan rumus sebagai berikut :

$$
\begin{gathered}
M i=\frac{1}{2}(\text { Skor maksimal ideal } \\
+ \text { Skor terendah ideal }) \\
S D i=\frac{1}{6}(\text { Skor maksimal ideal } \\
\quad-\text { Skor terendah ideal })
\end{gathered}
$$

5) Uji Respon Pengguna

Hasil dari respon pengguna dilakukan untuk mengetahui kepuasan dan tanggapan pengguna tentang film pembelajaran bina diri daily living skill. Uji respon pengguna dilakukan dengan cara menyebarkan angket kepada 20 siswa di SLB Negeri 2 Buleleng yang terdiri dari 5 siswa SD, 10 siswa SMP, dan 5 siswa SMA, hasil perhitungan respon pengguna sebagai berikut :

$$
p=\frac{f}{n} x 100 \%
$$

$p=$ persentase

$\mathrm{f}=$ frekuensi dari setiap jawaban angket / jumlah total

$\mathrm{n}=$ jumlah skor ideal

$100=$ bilangan tetap

Persentase Hasil $=1650 / 20$

$$
=82,50 \%
$$

\section{Pembahasan}

Pengembangan film pembelajaran bina diri daily living skill merawat pakaian dan mentaati tata tertib berlalu lintas terdapat beberapa perangkat lunak yang dibutuhkan dalam pengembangannya yang pertama yaitu Audacity, untuk mengolah hasil rekaman yang digunakan pada narasi objek 3D, selanjutnya untuk mendukung pengembangan aplikasi ini khususnya di bagian grafis, peneliti menggunakan Blender untuk membuat objek 3D dan animasi yang berupa VFX. Selanjutnya dilakukan proses compositing dengan menggunakan aplikasi adobe premier pro cc 2017 untuk menggabungkan video dari tiap scene seperti penambahan subtitle, credit, dan color grading. Selanjutnya diteruskan pada tahap implementasi.

Tahap implementasi adalah tahap saat media telah siap untuk diperkenalkan dan dilakukan pengujian kelayakan. Pada tahap ini dilakukan implementasi film pembelajaran bina diri daily living skill merawat pakaian dan mentaati peraturan lalu lintas pada anak-anak di Sekolah Luar Biasa Negeri 2 Buleleng yang akan dijadikan sebagai responden.

Pada evaluasi tahap ini lebih difokuskan pada hasil dan isi dari tahap pengembangan. Hasil pengembangan seperti pada konten atau isi dilakukan uji validitas oleh para ahli isi dalam hal ini peneliti melibatkan 2 guru mata pelajaran 
bina diri di SLB Negeri 2 Buleleng, untuk mengetahui kesesuaian media yang dirancang dengan isi materi pembelajaran. Hasil yang di dapat dari uji validitas isi oleh para ahli isi yaitu pada tahap pertama mendapat kesesuaian $80 \%$ mengingat terdapat ketidaksesuaian, adapun ketidaksesuaian dari ahli isi yaitu pada kejelasan informasi berupa penekananpenekanan, dan layout tata letak, kemudian dilakukan revisi dan kembali dilakukan uji validitas ahli isi tahap kedua mendapat kesesuaian sejumlah $100 \%$. Ini menandakan bahwa isi dari media sudah sesuai dengan materi dan tujuan pembelajaran.

Pengujian validitas juga dilakukan oleh dua ahli media dan desain, dalam hal ini peneliti melibatkan dosen dari program studi pendidikan teknik informatika UNDIKSHA, pengujian ini dilakukan untuk mengetahui kesesuaian rancangan dan implementasi. Hasil dari pengujian validitas media dan desain peneliti mendapatkan kesesuaian sebesar $100 \%$ namun terdapat masukan dan saran adapun masukan dan saran diantaranya yaitu kualitas gambar ditingkatkan, penggunaan bahasa indonesia yang baik pada subtitle dan sudah direvisi. Hal ini menandakan bahwa rancangan dan hasil media yang peneliti kembangkan sudah sangat sesuai dengan materi dan tujuan pembelajaran.

Setelah melakukan uji validitas ahli isi, media dan desain peneliti juga melakukan uji oleh guru, hal ini dilakukan untuk mengetahui respon guru terhadap kesesuaian media yang dikembangkan dengan pembelajaran yang guru terapkan di sekolah. Dalam hal ini peneliti melibatkan guru mata pelajaran bina diri di SLB Negeri 2 Buleleng yang merupakan tempat penelitian. Hasil dari uji guru ini peneliti mendapatkan hasil dengan kriteria sangat positif.

Setelah melakukan uji validitas pada penelitian ini peneliti melanjutkan dengan melakukan evaluasi uji respon penonton untuk mengetahui respon pengguna setelah menggunakan media yang peneliti kembangkan. Jumlah responden yang peneliti gunakan dalam pengujian respon ini adalah 20 orang. Dengan pembagian 5 orang responden di kalangan SD, dan 10 orang responden dikalangan SMP dan 5 orang responden dikalangan SMA dilingkungan SLB Negeri 2 Buleleng.

Dari hasil analisis uji respon pengguna tersebut didapatkan rata-rata persentase respon dari 20 responden yaitu sebesar $82,5 \%$. Pengujian dilakukan menggunakan skala linkert. Skala linkert digunakan untuk mengukur sikap, pendapat dan persepsi seseorang atau kelompok tentang fenomena sosial. ${ }^{[10]}$

Selain melakukan uji respon pengguna, evaluasi terakhir pada penelitian ini peneliti melakukan uji efektivitas untuk mengetahui tingkat efektivitas media film pembelajaran serta mengetahui tingkat pemahaman anak-anak.

Setelah media film pembelajaran diterapkan, maka peneliti menyebarkan angket pre test dan angket post test pada beberapa kelompok kecil yang dibantu oleh guru kelas. Hasil yang didapatkan dari pembagian soal pre test dan post test dapat dilihat pada gambar 14 .

representasi awal sebelum di adakannya penggunaan media sebesar $65 \%$ kemudian setelah dilakukan pemuteran media film pembelajaran sebanyak 2 kali pertemuan, peneliti kembali menyebarkan angket post test dan didapatkan hasil sebesar $84,06 \%$. Pada uji efektifitas peneliti menggunakan perhitungan $\mathrm{N}$-gain dimana Gain adalah peningkatan kemapuan yang dimiliki siswa setelah pembelajaran. Gain diperoleh dari selisih antara hasil pretest dan posttest. $\mathrm{N}$ Gain adalah gain yang ternormalisasi, perhitungan $\mathrm{N}$-gain ini bertujuan untuk menghindari kesalahan dalam menginterprestasikan perolehan gain dari seorang siswa. ${ }^{[5]}$

Setelah dihitung menggunakan rumus $N$-gain peneliti mendapatkan hasil dengan representasi sebesar $54,45 \%$ yang jika dilihat dari tabel $\mathrm{N}$-gain, hasil tersebut masuk dalam kategori sedang, ini menandakan bahwa media yang dikembangkan cukup efektif. 


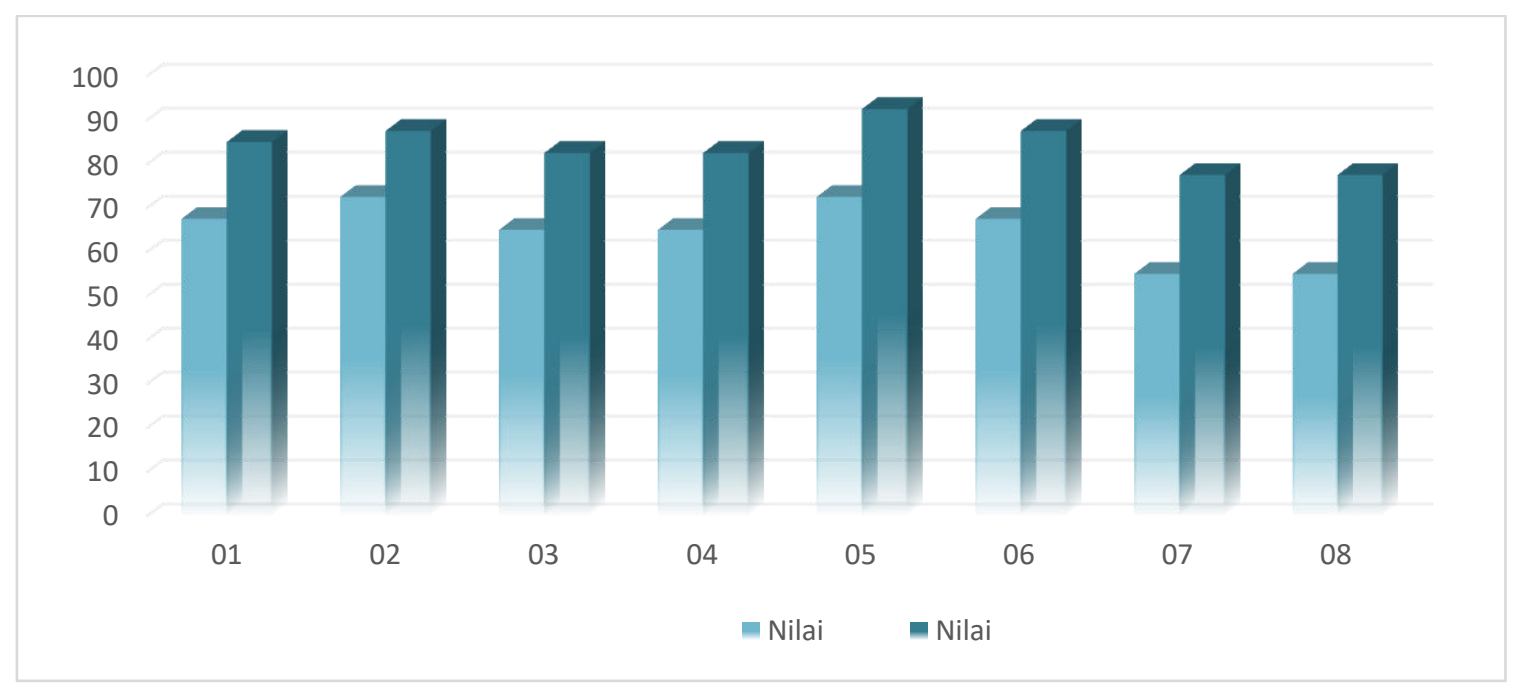

Gambar 11. Hasil Uji Efektifitas

\section{SIMPULAN}

Berdasarkan hasil analisis, desain, pengembangan, implementasi, dan evaluasi pada penelitian pengembangan film pembelajaran bina diri daily living skill merawat pakaian dan mentaati tata tertib berlalu lintas peneliti dapat menarik kesimpulan sebagai berikut :

Pengembangan film pembelajaran bina diri daily living skill merawat pakaian dan mentaati tata tertib berlalu lintas menggunakan beberapa aplikasi dalam mendukung proses pengembangan yaitu Blender untuk pembuatan karakter 3D dan animasi VFX, kemudian audacity dan adobe audition digunakan untuk merekam dan mengedit suara narasi maupun dialog, serta adobe premire digunakan pada proses akhir penggabungan video, efek suara, musik, title dan subtitle.

$$
\text { Pengembangan media film }
$$

pembelajaran bina diri daily living skill merawat pakaian dan mentaati tat tertib berlalu lintas peneliti melakukan uji validitas ahli isi dan uji validitas ahli media dan desain untuk memastikan kelayakan media film pembelajaran yang dikembangkan. selain dilakukan uji validitas ahli peneliti juga melakukan uji respon pengguna yaitu kepada siswa di SLB Negeri 2 Buleleng dengan mendapatkan respon positif. Dari hasil uji respon di lapangan terhadap 20 anak-anak yang dijadikan responden dalam melihat kelayakan film pembelajaran di dapatkan hasil sebesar $82,5 \%$ yang artinya media film pembelajaran bina diri daily living skill merawat pakaian dan mentaati tata tertib berlalu lintas masuk dalam kategori baik.

\section{REFERENSI}

[1] Astati. (2013). Apa itu program Bina Diri ? Retrieved from INFO KMOE INFORMASI DAN REFERENSI PENDIDIKAN:

https://www.infokmoe.id/2013/06/apaitu-program-bina-diri.html

[2] Branch, R. M. (2009). Intructional Design:The ADDIE Approach. New York: Springer.

[3] Direktorat Pembinaan Sekolah Luar Biasa. 2006. Panduan Pelaksanaan Kurikulum Pendidikan Khusus. Jakarta: Balai Pustaka

[4] Gina, E. P. (2014). Pengembangan Media Video Mata Pelajaran Keterampilan Menyulam untuk Siswa 
Tunagrahita Ringan Kelas XII di SMA Luar Biasa Negeri 1 Yogyakarta. Jurusan Teknik Busana, Universitas Negeri Yogyakarta, 2-3.

[5] Hartini, R., Santyadiputra, G. S., \& Pradnyana, G. A. (2017). PENGEMBANGAN FILM PEMBELAJARAN ILMU PENGETAHUAN ALAM UNTUK SEKOLAH DASAR (Studi Kasus: Kelas 5 SD No. 7 Benoa). Jurnal Pendidikan Teknologi dan Kejuruan, 14(2).

[6] Herawati, P. (2016). PENGEMBANGAN LEMBAR KERJA PESERTA DIDIK (LKPD) INTERAKTIF UNTUK PEMBELAJARAN KONSEP MOL DI KELAS $X$ SMA. Jurnal Penelitian Pendidikan Kimia, Vol. 3 No. 2 Hal. 168172.

[7] Munadi, Y. (2013). Media Pembelajaran. Jakarta Selatan: GP Press Group.

[8] Sanjaya, W. (2012). Media Komunikasi Pembelajaran. Jakarta: Kencana.

[9] Sanjoya, I. (2016). Materi Story Board. Retrieved from DocSlide: Http://dokumen.tips/documents/materi03-Story-Board.html.

[10] Suciningsih, K. (2013). Pengembangan Video Pembelajaran Pada Mata Pelajaran Bahasa Indonesia Kelas III Semester II Tejakula. Buleleng: Undiksha.

[11] Sugiono. (2011). Metode Penelitian Kuantitatif Kualitatif dan R\&D. Bandung: ALFABETA, CV.

[12] Undang-Undang Republik Indonesia No.33 Tahun 2009 tentang Perfilman Nasional, 2009. Jakarta:PT Arnas Duta Jaya

[13] Wibowo, A. (2010). Penggunaan Media Film dan Metode Bermain Peran untuk Meningkatkan Pemahaman Siswa Tentang Sejarah Proklamasi Indonesia . Sarjana UPI 